\title{
特別講演
}

\section{Community-based Rehabilitation}

\section{Antonio 0. Periquet, MD*}

\section{リハビリテーションの意味と現状}

1981 年に国際連合により宣言された国際障害者年の 中で明らかにされた驚異的事実の一つは，各国人口の $10 \%$ が精神障害者または身体障害者であると推定され ることであった。この状況は，多くの人々がリハビリ テーション・サービスへのアクセスを持なない開発途 上国で特に深刻である。障害の発見や処置は遅れ，最 初はごく軽度の能力低下 (disability) しかなくとも， 二次的機能障害（impairment）を起こし，ついには重 度で永続的な能力低下の状態に陷る者も多い。

開発途上国の国民の大多数は田舎に住んでいる。し ながって，それに応じた頻度で障害者が田舎で見られ ることになるが，しかし，田舎における保健ケア機関 のレベルを考えに入れるならば，それよりも高率で見 られるかもしれない。一方，リハビリテーションの専 門機関やセンターは大都市に集中している. その存在 は，それを利用できる経済的余裕のあるものにとって は非常に価值あるものだけれども，地理的条件や経済 状況のために基本的で最低限の保健ケアに対するアク セスすらない者にとって，リハビリテーション機関は 何の意味も持なない.

リハビリテーション・センターの建設と運営には多 額の費用がかかるものである。高度技術による設備が 必要だが, 電力供給が不規則であったり, 全くないよ うな地域において，それらの多くは単に場違いなな゙け でなく，むしろ設置することが馬鹿げてさえいる．部 品の確保は困難なことも多い. 維持と補修の能力はし ばしば劣覀である。これらのセンターは高度な訓練を 受けな専門家が必要だけれども, 彼らは都市で職がな かったとしても田舎へ行こうとはしない，彼らは，給
料が高くて労働条件のよい先進国にあこがれている. リハビリテーション・センターにおける入院サービス の質は高いのだが，外来での経過観察の質は低い。な ぜなら，交通手段は限られているし，通院による出費 がかさむからである。

\section{リハビリテーションの変革}

状況は変革を要求している。 Community-based Rehabilitation (CBR) が，その変革をもたらす.

$\mathrm{CBR}$ とは「コミュニティの資源に依拠して，コミュ ニティ・レベルで対処するアプローチである」と世界 保健機関 (WHO) は定義している.そして，このコミ ユニティの中には, 機能障害, 能力低下, 社会的不利 (handicap) のある者自身，彼らの家族と，そのコミュ ニティ全体が含まれるものである。それは，世界保健 機関が提唱しているプライマリー・ヘルス・ケアの構 成要素である。

CBR の原点は, 1978 年にアルマ・アタというロシア の無名の街で行われた国際会議に求められる。この会 議は,「今後 10 年間における各国政府と世界保健機関 の主要目標は, 西暦 2,000 年までに世界中のすべての人 間を社会的・経済的に生産的な生活を営めるような健 康状態に到達させることである」という決議を実現さ せる手段がプライマリー・ヘルス・ケアであることを 確認した。

\section{障害における}

リハビリテーションの実際

障害に関連する分野では，2つのプログラム領域が 考えられる。

1 ）機能障害を予防する対策の促進

* 1989 年 6 月 1 日，仙台市・仙台市泉文化創造センターにて講演

** Republic of Philippines Department of Health Office of the Secretary 
もし機能障害が予防されれば，能力低下は発生しな いし，時間も費用もかかるリハビリテーションも必要 ないであろう。

2) リハビリテーション・サービスの供給

能力低下は常に予防できるものではない，能力低下 が生じた時, その犠牲者を正常または最大限の高い機 能レベルの状態まで回復させるために, リハビリテー ション・サービスが必要になる。

\section{1.リハビリテーション第 1 レベル：CBR}

能力低下の性質と複雑さに応じてリハビリテーショ ンには相互に連係しあう 3 つのレベルがあり，CBRは その中の第 1 段を構成するものである.プライマリ一・ ヘルス・ケアの精神では, CBRは, 地域ワーカー, 障害者の家族, 地方機関, そして障害者の家庭で行わ れるサービスの組織を包括している。キー・パーソン は, 身体, 視覚, 聴覚, 精神の 4 つの障害領域で, リ ハビリテーションの簡単で基本的な技術を習得してい るコミュニティの一員である.彼は「地域指導者 (local superviser：LS)」と呼ばれる. 訓練が終了すると, 彼 は自分の担当地域の障害者家庭へ行き, 障害者の家族 がリハビリテーションを行えるように彼らを指導して いく.

\section{2. リハビリテーション第 2 レベル(中間レベル)}

次のレベルは中間レベルであり, 保健関連分野の教 育は受けているけれども，障害と特に関係したことの ない人々を活用するものである。それは，一般医家， 看護婦, 助産婦, 教師, ソーシャル・ワーカーと補助 的ワーカーである。彼らは CBR よりも高いレベルのケ アを行うための障害（能力低下）予防とリハビリテー ションに関する特別の課程を受けている。このレベル は，CBRにとって第一の紹介先であり，CBR を監視 し指導する責任をも有している.

\section{3. リハビリテーション第 3 次レベル}

3 次レベルは, 高度に専門化されたレべルであり, リ ハビリテーション・センター, リハビリテーション医 学, 特殊教育, 職業リハビリテーションと社会サービ スの施設により構成される。このレベルは, 研修, 複 雑な症例に対するサービス, 研究に関する最高の資源 である. CBR は施設に依拠したサービスに代わること を意図するものではなく，むしろ，それらを補完する ものであり, 施設サービスを求めて集まる 1 次・2 次 レベルの患者達による3 次レベル機関の混雑を緩和さ
せるものである。

\section{CBR の効用}

CBR が正しく組織され運営されれば,それはリハビ リテーションを必要としている人々の基本的ニーズを 低価で満たすものになる。完全ではないにしても専門 的訓練を受けたりハビリテーション従事者による簡単 で基本的なサービスの提供は，彼ら自身とコミュニテ イの人々との強固な社会的きずなにより補うれるもの である。

田舎で通常のリハビリテーション・サービスを提供 する際に最もよくみられる束縛を, CBR は効果的に解 決してくれる。その束縛とは，以下のものである。

1) 地理的障害。人口は各地域ごとに密集している が, 各々の地域は相互に大変離れており，それ をつなぐ道路も通信手段も劣悪である，島や山 岳地帯に住む者もいる。

2) コミュニティごとに障害のパターンが異なる.

3 ) 社会, 経済および文化的要因がコミュニティで さまざまである。

$\mathrm{CBR}$ の成否は, 関係政府機関と非政府組織とを連携 させるような統合的で包括的な構造の確立にかかって いる.コミュニティが CBRのプログラムを自分自身の ものと考えることができるように，コミュニティ自身 にも政策設定，意志決定，プログラムの遂行と評価の 過程に参加する機会が与えられるべきである。このこ とが成功の確率を上げる.

\section{リハビリテーション実践 のためのマニュアル}

地域指導が実践上の参考にできるように，WHOは 「コミュニティにおける障害者の訓練」というマニュア ルを作成した。このマニュアルには，障害者や家族を 訓練するうえで用いられる簡単で基本的なリハビリテテ ーション処置の方法に関する詳細な指導が示されてい る。このマニュアルで対象にしている障害は, 神経, 筋骨格, 視覚, 聴覚, コミュニケーション, それに精 神の各領域である。

このマニュアルは 5 冊子からなる.

1) 冊子 1 : 〈全般的情報〉マニュアル使用方法, 用語の定義，予防のレベル，障害の種 類.

2 ) 冊子 2 : 〈身体障害〉コミュニケーション障害, 能力低下予防, 簡単なリハビリテーシ 
ヨン技術。

3 ) 冊子 3 : 〈精神障害〉正常小児発達パターン, 一般的な行動および情緒上の問題，精 神発達遅滞の予防, 早期発見と処置.

4 ）冊子 4 : 〈プロジェクト管理〉CBRS 設置に関 する情報，紹介網の確立，プロジェク 卜の資金.

5 ）冊子 5 ：〈補遺〉用語集

\section{フィリピンにおける CBR の実際}

フィリピンでの CBR は以下の 3 相で展開されてい る.

\section{1. 第 1 相 : プロジェクトの立案, 場所の選択, 地域指導者の選択, 社会的準備}

CBR プロジェクト委員会は, プロジェクトの立案, 実施，監視，評価を担当するための組織である。 そし て，プロジェクトの場所の選択は，それを引き受ける コミュニティ自身の興味と熱意をもとになされる。ま た, 地域指導者の選択は, 彼ら自身のプロジェクトに 对する関与の程度や 1 日 $2 \sim 3$ 時間以上を障害者とと もに働こうという気持ちをもとになされる，彼らは， 自分が㗢くコミュニティの住民でなければならない。

社会的準備はCBRの重要な要素であり,それが受け 入れられるための道を開くものである.プロジェクト をコミュニティに導入し，受け入れを高めて活発な参 加を促すための活動が組織される，徽底的な情報キャ ンペーンが展開され，それは集会，新聞，ラジオ，テ レビ，折り込み，さらに印刷物の配布によりなされる. コミュニティの発展に対するこのプロジェクトの意義 が強調される。

この段階で紹介のためのシステムが確立される。そ の連結には 2 つの構成要素がある。

(1)垂直：2 次あるいは中間レベルおよび 3 次あるい は施設レベルに対して。

(2)水平 : 特殊教育, 職業リハビリテーションや社会 サービスのような医療以外の領域に対して。

\section{2 . 第 2 相：地域指導者の訓練}

\section{1 ) 訓練}

訓練は理想的にはリハビリテーション医学の専門家 により行われる。フィリピンでは，それはリハビリテ 一ション専門医, 理学療法士, 作業療法士, 言語療法 士からなるリハビリテーション医学科のス夕ッフによ
るワークショップで行われた。他の参加者は, 小児科 医, 精神科医, 特殊教育教師, さらに他の関連領域の 者であった。訓練方法は, 講義, 実演, 役割演技法で ある．授業ではマニュアルの使用が強調される。

\section{2 ) 実際}

訓練が終了すると, 地域指導者には担当の障害者が 与えられる。第 1 相でコミュニティにおいて障害者の 住んでいる場所が調べられている，退院後の経過観察 を CBR 担当者が行えるように, 病院との打ち合わせも なされる。

まず地域指導者が患者にリハビリテーションの処置 を行い，それと同時に，指導者は患者の家族に方法を 教えていく，最終的には，地域指導者の監督のもとで 家族が実際のリハビリテーション過程を受け持つので ある。

地域指導者は以下の書類に記入することが求められ ている.

1) 症例経歴書

障害者の名前, 能力低下の種類, 性質, 程度が含ま れる。これは最初の訪問の際に地域指導者により記入 される。

2 ) 訓練マニュアル使用書

マニュアルのどの部分を地域指導者が使ったか明ら かにし，マニュアルの有効性や使いやすさを評価する.

3 ）経過報告書

予定められている尺度に基づいて経過を記載する。

\section{3 . 第 3 相：監視と評価}

この相の目標は以下のものである。

(1)プロジェクト実施の評価

(2)他の領域への紹介を要する患者の同定

(3)特殊なニーズの決定

プログラム調整者による地域指導者とのフィード・ バックのための会が持たれる。問題は議論され，ニー ズは分析され，それらにより将来の計画と訓練の基盤 が作られる。

\section{CBR 実施に伴う問題と結果の評価}

CBR 実施に伴う問題で多かったのは以下の通りであ る.

(1)紹介のニーズを支える 2 次および 3 次サービスの 不足または欠如

(2)いくつかの機関における障害とリハビリテーショ ンに関する情報不足, それに伴う優先度の低さ 
(3)初期段階では地域指導者に対する信頼が確立して いなかったために，家族の協力を得ることの困難 巳

(4)地域指導者の役割に対する誤解

(5)リハビリテーション従事者を集めることの困難さ

1985 年に, 結果の評価が別個の調查グループにより 行われ，139人の障害者が聞き取り調查をされた。以 下の項目が評価された。

\section{1) 身体的パフォーマンス}

以前は食事捸取で完全または部分的に介助を受けて いた障害患者の $2 / 3$ が完全に自立した。 10 人中 6 人 が整容の点で改善し, $2 / 3$ がトイレや入浴活動で完全 または部分的に自立した。大部分の者がトランスファ 一活動で改善し，4 人中 3 人で移動能力が改善した. 階段を上つたり，坂道・勾配を通るような身体の上方 移動の活動でもパフォーマンスは改善した。

\section{2 ) 社会的技能}

10 人中 7 人が, 他人の言うことを理解したり, 他人 に理解されたりする点での改善を示した. 10 人の子供 のうち 6 人が他の子供と遊べるようになったし, 大多 数でコミュニティ活動への参加が促進された。しかし， 介助のもとで学校へ通えた者は $1 / 3$ にすぎなかった。

\section{3 ）自己に関する価値観}

$2 / 3$ が他人との相互理解の能力を改善させた. $2 / 3$ 以上は他人が自分のことをどう思っているかを心配し なくなった，しかし，大部分の者は他人と一緒に自分 自身のことを笑えるようにはならなかった。

\section{4) 自立}

$2 / 3$ が終日の付き添いを必要としなくなった。しか し, 2 / 3 以上の者がある場所から別の場所への移動時 に介助を要した. $45 \%$ 者は自分のしたいことをする 点で改善し, 同時に, $2 / 3$ の者は自分の能力が人に知 られることを何とも思わなくなった。

\section{5 ) 発達課題}

10 人の子供のうち 7 人が学校へ行きたいと希望する ようになった. $45 \%$ 以上の者が将来に対する計画を持 つようになった。しかし，仕事に出たいという意四を 示した者は $20 \%$ にすぎなかった。

\section{6 ) 社会への統合}

$47 \%$ 者が市場入行くようになったり, 行く回数が 增えた. $48 \%$ 者が学校へもつと規則的に通うように なった。医師や歯科医への受診回数が増えた。10 人中 7 人以上の者が文化活動にもっと参加するようになった し，友人や親墄を訪衫る回数も增えた。
障害者の中では 13 ～ 19 歳までの年齢層が最も多か つた，移動の問題が最も多い障害であり，それに視覚 障害, 重複障害, 精神発達遅滞, 聴覚と言語の障害が 続いた。

CBRS は低価の介入システムであり, 紹介とサービ 又提供に関する各機関の協調の概念とリハビリテーシ ヨン活動に対するコミュニティのボランティア精神の 概念を利用したものであると調查は結論付けた。それ は障害（能力低下）予防とリハビリテーションの概念 を草の根レベルまで引き下げることがある程度までは 実現可能であるということを示してくれた。

障害（能力低下）予防とリハビリテーションの実施 にとって CBRS は簡単で費用面でも効果的な方法であ り，リハビリテーション・サービスに対するアクセス が少ないか久如している田舎において特にCBRSはふ さわしい存在なのだということが結論である. CBRは 障害者を改善させ，それにより家族の関心と熱意は保 たれた。フィリピン総合病院の地域リハビリテーショ ン医と訓練チームによる評価では, 能力低下を生む機 能障害の自然回復過程からでは説明しがたいほどの有 意かつ確実な機能的パフォーマンスの改善が示された。

\section{CBR の将来}

日本のような先進国に対しても CBR は重要な示唆を 与えるものである。最良のケアを受けるためには, 最 も高価で複雑な技術や処置を利用しなければならない という哲学が現在広く受け入れられているが, CBR は この哲学に対して疑問を投げかけるものである.「サー ビスの適正レベル」，すなわち，「資源利用の階層性は ニーズの階層性に根ざすのが最良である」という原理 をCBRは説くものである.この原理はリハビリテーシ ヨン分野で進行している人員不足に対する解決策を提 供するものであり，「自分で行え (do it yourself)」を 求める声の高まりと, 自助のためのリハビリテーショ ン機器の進歩にも応えるものである，専門外の人，素 人，コミュニティ・ワーカーや家族が本当に問題を解 決できるようになれるのであり，また，マニュアルで 期待した以上に彼らがリハビリテーション・プログラ ムの技術面を行うことができたということを CBR は実 証した。家族とコミュニティは率先して障害者のニー ズを評価し，きわめて精巧にまた創造的に障害者と付 き合っていけるように他の家族を援助するようになっ た。しかし，今後はCBRの弱点を技術面だけでなく社 会展望の面からも分析していく必要がある. 
他の関連プログラムと同様に, CBR は有能なコミュ ニティの育成, 知識の神秘性の剝奪, 情報へのアクセ スの簡易化を目指すものである. CBR は 3 次レベルの 施設ケアと特殊サービスを補完するような自助の状況 を作り出すものであり，それによって，3 次レベルが リハビリテーションのより複雑な問題に専念できるよ うに解放するものである。

CBR は障害者のためにこれまで未踏であった領域へ 浸透しよjとするものである。それは，単に機能と責 務の発展によって効率的で効果的なプログラムの施行 を計るだけでなく，実現可能な方法でリハビリテーシ ヨン・サービスをコミュニティのレベルまで広範に到 達させることを目指すものである。それは資金，人員， 時間の問題に対する一つの解決をもたらしている。そ れは特に田舎における障害（能力低下）予防とリハビ リテーションに対する最も論理的な戦略なのである。

\section{〔特集〕脊髄損傷の合併症・随伴症}

尙髄損傷における病性と筋痤攣について‥大阪労災病院リハ馀療科 川村次郎・他 尙髄損傷者の自律神経障害…………………産業医大リ八医学 井上和宏・他 裖瘡 九州労災病院り八㢵療科 吉村 理・他 異所性骨化……………………水俣市立湯之児病院リハセンター 浅 山 滉 尙髄損傷に伴う疼痛…………………神奈川リハ病院リハ医学科 大橋正洋・他

\section{0年 1 部定価 $¥ 1,957$ (税込み) 年ぎめ予約購読料 $¥ 22,248$ (税込み)}

$\diamond$ 編集顧問 小野啓郎, 宮崎一興, 豊倉康夫, 長島親男

$\diamond$ 編集委員 萬年 徹, 高橋 昭, 田代邦雄, 土田正義, 小柳知彦, 近藤厚生, 大橋正洋, 吉村 理, 河合伸也, 金田清志, 平林 洌, 辻 陽雄, 小山素麿, 矢田賢三, 角家、暁, 白馬 明

$\diamond$ 編集幹事 服部孝道, 渡部恒夫, 三井公彦 